\title{
PLANTAR PRESSURE ANALYSIS OF VOLLEYBALL PLAYERS BASED ON GAIT FEATURES
}

\author{
Zegang WANG* \\ Xichang University, Xichang 615000, China, wangzegang@126.com \\ Received: 06.05.2019 \\ Accepted: 12.09 .2019 \\ https://doi.org/10.24264/Ifj.19.3.3
}

\section{PLANTAR PRESSURE ANALYSIS OF VOLLEYBALL PLAYERS BASED ON GAIT FEATURES}

ABSTRACT. Due to long-term intense training, volleyball players are more likely to suffer from high pressures in some places of the sole than ordinary people. Sustained exposure to such a high pressure will lead to foot eversion/inversion and different degrees of sports injuries, posing a serious threat to the sports career. Gait features have long been recognized as a major impactor of plantar pressure, but have not been applied to analyze the plantar pressure of volleyball players. To make up for the gap, this paper introduces gait features to the plantar pressure analysis of volleyball players. Professional volleyball players and ordinary people were separately allocated to the test group and the control group, and subjected to contrastive test. The gait features were recorded by a special device. On this basis, the author analyzed the plantar pressure collected in the test, trying to disclose the effects of gait features on plantar pressure and disease of volleyball players. The research results show that: (1) Volleyball players differ greatly from ordinary people in gait features; (2) The uneven distribution of plantar pressure is a major cause of plantar diseases of volleyball players; (3) Changing the gait features helps make the distribution of plantar pressure more uniform, and thus effectively control the risk of plantar diseases. This paper innovatively introduces gait features into the analysis on plantar pressure of volleyball players, and proves that plantar pressure distribution varies with gait features. Of course, gait features are not the only influencing factors of plantar pressure. The future research will explore the other factors that affect the plantar pressure of volleyball players. KEY WORDS: Gait features, plantar pressure, sports injuries, volleyball

\section{ANALIZA PRESIUNII PLANTARE LA JUCĂTORII DE VOLEI PE BAZA CARACTERISTICILOR MERSULUI}

REZUMAT. În urma antrenamentelor intense pe termen lung, jucătorii de volei sunt mai susceptibili să sufere de presiuni mai ridicate în unele zone ale tălpii decât oamenii obişnuiți. Expunerea susținută la o presiune atât de ridicată va duce la eversiunea/inversiunea piciorului și la leziuni sportive de diferite grade, reprezentând o ameninţare serioasă pentru cariera sportivă. Caracteristicile mersului au fost recunoscute de mult timp ca un factor important al presiunii plantare, dar nu au fost aplicate pentru a analiza presiunea plantară la jucătorii de volei. Pentru a compensa decalajul, această lucrare introduce caracteristicile de mers în analiza presiunii plantare la jucătorii de volei. Jucătorii de volei profesionişti şi oamenii obişnuiţi au fost împărţiţi în grupuri de test şi grupuri martor şi au fost supuşi unui test de contrast. Caracteristicile mersului au fost înregistrate cu un dispozitiv special. Pe această bază, s-au analizat valorile presiunii plantare colectate în test, în încercarea de a dezvălui efectele caracteristicilor mersului asupra presiunii plantare și leziunilor jucătorilor de volei. Rezultatele cercetării arată că: (1) jucătorii de volei diferă foarte mult de oamenii obişnuiţi în ceea ce priveşte caracteristicile mersului; (2) distribuţia inegală a presiunii plantare este o cauză majoră a leziunilor la nivel plantar la jucătorii de volei; (3) modificarea caracteristicilor mersului contribuie la uniformizarea distribuţiei presiunii plantare şi, astfel, la controlul eficient al riscului de leziuni la nivel plantar. Această lucrare introduce în mod inovator caracteristicile mersului în analiza presiunii plantare la jucătorii de volei şi dovedeşte că distribuția presiunii plantare variază în funcţie de caracteristicile mersului. Desigur, caracteristicile mersului nu reprezintă singurul factor care influenţează presiunea plantară. Cercetările viitoare vor explora alţi factori care afectează presiunea plantară la jucătorii de volei.

CUVINTE CHEIE: caracteristicile mersului, presiune plantară, accidentări sportive, volei

\section{L'ANALYSE DE PRESSION PLANTAIRE DES JOUEURS DE VOLLEYBALL À PARTIR DES CARACTÉRISTIQUES DE LA MARCHE}

RÉSUMÉ. Après un entraînement intensif à long terme, les joueurs de volleyball sont plus susceptibles que les gens ordinaires de subir des pressions plus fortes dans certaines zones de la plante du pied. L'exposition à une pression aussi élevée entraînera une éversion/inversion du pied et des blessures sportives à des degrés divers, représentant une menace sérieuse pour la carrière sportive. Les caractéristiques de la marche sont reconnues depuis longtemps comme un facteur important de la pression plantaire, mais elles n'ont pas été appliquées pour analyser la pression plantaire chez les joueurs de volleyball. Pour compenser cet écart, cet article présente les caractéristiques de la marche dans l'analyse de la pression plantaire chez les joueurs de volleyball. Les joueurs de volleyball professionnels et les gens ordinaires ont été divisés en groupes de test et en groupes de contrôle et ont subi un test de contraste. Les caractéristiques de la marche ont été enregistrées avec un appareil spécial. Sur cette base, les valeurs de pression plantaire recueillies lors du test ont été analysées afin de révéler les effets des caractéristiques de la marche sur la pression plantaire et les blessures des joueurs de volleyball. Les résultats de la recherche montrent que : (1) les joueurs de volley-ball diffèrent considérablement des gens ordinaires en termes de caractéristiques de marche ; (2) la répartition inégale de la pression plantaire est une cause majeure de blessure plantaire chez les joueurs de volleyball ; (3) la modification des caractéristiques de la marche contribue à l'uniformité de la répartition de la pression plantaire et, ainsi, à la maîtrise efficace du risque de blessures au niveau de la plante plantaire. Cet article introduit de manière innovante les caractéristiques de la marche dans l'analyse de la pression plantaire chez les joueurs de volleyball et prouve que la distribution de la pression plantaire varie en fonction des caractéristiques de la marche. Bien entendu, les caractéristiques de la marche ne sont pas le seul facteur influant sur la pression plantaire. Des recherches futures exploreront d'autres facteurs qui affectent la pression plantaire chez les joueurs de volleyball. MOTS CLÉS : caractéristiques de la marche, pression plantaire, blessures sportives, volleyball

\footnotetext{
* Correspondence to: Zegang Wang, Xichang University, Xichang 615000, China, wangzegang@126.com
} 


\section{INTRODUCTION}

The foot is under greater pressure than any other organ in human body. During motion, different parts of the foot carry varied degrees of pressure. For an adult, the pressure on foot is on average 1.5 times the body weight when he/she is walking, and will grow to $3 \sim 4$ times the body weight when he/she is running [1]. The pressure on foot, especially the plantar pressure, can reflect the motion state of the body. So far, plantar pressure has mainly been explored from the perspective of gait, which directly affects the distribution of plantar pressure [2]. Of course, the distribution is also influenced by many other factors [3]. By analyzing plantar pressure, it is possible to evaluate the healthiness of our gait, and prevent injuries in fitness programs and competitive sports. As a result, the distribution of plantar pressure has become the focal point of foot research, and a major concern in important fields like sports mechanics and rehabilitation.

Due to long-term intense training, volleyball players are more likely to suffer from high pressures in some places of the sole than ordinary people. Sustained exposure to such a high pressure will lead to foot eversion/inversion and different degrees of sports injuries, posing a serious threat to the sports career [4]. The threat is particularly high in the sport of volleyball, which requires frequent running and jumping.

Cappozzo (1995) conducted biomechanical analysis of athletes' sole with plantar pressure test system and infrared motion tracking system, revealing significant difference between landing and jumping in plantar pressure distribution [5]. However, the plantar pressure of volleyball players has not been analyzed specifically in the existing research on sports medicine, not to mention the relationship between gait features and plantar pressure or sports injury of volleyball players. To make up for the gap, this paper carefully measures and analyzes their plantar pressure and gait features of volleyball players, identifies the root causes of plantar pressure, and clarifies the relationship between gait features and sports injuries. On this basis, the author put forward suggestions on how to effectively protect the foot.

After exploring various types of sports, Riva et al. (2012) concluded that exercise fatigue affects gait, which in turn changes plantar pressure distribution, and that the fatigued gait is highly likely to cause sports injuries [6]. Schmid et al. (1997) discovered that gait is greatly affected by motion speed and intensity: the time and carrying capacity of each step change with the increase in motion speed and intensity, pushing up the plantar pressure [7]. Riva et al. explored the plantar pressure distribution of players in heel-and-toe walking, pointing out that the midfoot is critical to the body control and exertion. Schmid et al. compared athletes with and without knee joint injuries; the results show that injured athletes had more unfavorable distribution of plantar pressure, which comes from the incorrect gait.

\section{METHODOLOGY}

\section{Subjects}

A total of 47 subjects were selected, including 30 volleyball players and 17 ordinary people. The volleyball players and ordinary people were respectively allocated to the test group and the control group. The two groups were designed to observe the difference between volleyball players and ordinary people in gait features. The test group was further divided into two subgroups: a subgroup of 17 volleyball players with plantar diseases and a subgroup of 13 volleyball players without plantar diseases. The two subgroups help to disclose how the difference in gait features affects the plantar diseases of volleyball players. The 30 volleyball players were selected from a sports school. All of them have been engaging in the sport of volleyball for more than 5 years, and remain active in volleyball training or volleyball matches. The test plan has passed the ethics review by Xichang University (Review No.: 20171207235). The basic and injury conditions of the subjects are listed in Table 1. 
Table 1: The basic conditions of the subjects

\begin{tabular}{lcccccc}
\hline \multicolumn{1}{c}{ Groups } & Number & Age (year) & Height $(\mathrm{cm})$ & Weight $(\mathrm{kg})$ & Sports life (year) & BMI $\left(\mathrm{kg} / \mathrm{m}^{2}\right)$ \\
\hline Test group & 30 & $22.47 \pm 1.29$ & $197.21 \pm 2.46$ & $85.47 \pm 11.41$ & $8.25 \pm 1.12$ & $19.1 \pm 0.89$ \\
$(1) \quad$ Injured & 17 & $23.22 \pm 1.09$ & $198.35 \pm 3.86$ & $87.49 \pm 13.59$ & $9.21 \pm 1.62$ & $19.4 \pm 0.91$ \\
$(2) \quad$ Uninjured & 13 & $21.95 \pm 1.87$ & $176.26 \pm 2.52$ & $84.32 \pm 6.78$ & $7.23 \pm 2.52$ & $18.9 \pm 0.54$ \\
Control Group & 17 & $21.85 \pm 1.01$ & $177.21 \pm 4.52$ & $72.38 \pm 8.52$ & -- & $21.7 \pm 1.01$ \\
\hline
\end{tabular}

\section{Test Equipment, Site and Procedure}

The experimental equipment includes a plantar pressure tester, two cameras (with tripod) and one laptop. The experiment was carried out on in a quiet room $\left(>40 \mathrm{~m}^{2}\right)$ with level ground. The main procedure consists of the following steps:

(1) Calibrate the plantar pressure tester;

(2) Set up the cameras and align them to the test area from two angles, make recordings and provide data for dynamic analysis;

(3) Provide adaptive training to the subjects on barefoot;

(4) The trained subjects walk forward at the normal speed, step on the plantar pressure tester with one foot, and then turn back and step on the tester with the other foot.

The gait data were collected on the afternoon of December 15, 2017. During the collection, each subject was asked to walk, run or jump for $10 \mathrm{~min}$ in the collection area. The plantar pressure was captured by the tester, and the gait features were tracked by the cameras. After $10 \mathrm{~min}$, all collected data were imported to the computer for analysis on gait features and plantar pressure.

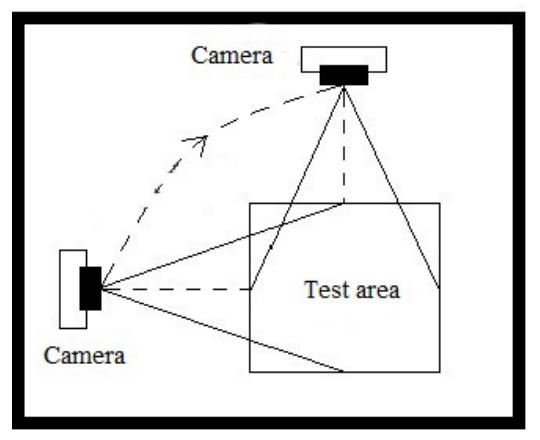

Figure 1. The test site

\section{Division of Plantar Pressure Zones}

Human foot has 26 bones, 33 joints and numerous muscles and ligaments [8]. These components form a complex structure that supports body weight, absorbs impact and maintains balance [9-10]. Most scholars have divided the sole into different zones before studying the plantar pressure [11-14]. As shown in Figure 2, the zones include the first toe (Zone 1: T1), the second to fifth toes (Zone 2: T2 5), the first metatarsal bone (Zone 3: $M 1$ ), the second metatarsal bone (Zone 4: M2), the third metatarsal bone (Zone 5: M3), the fourth metatarsal bone (Zone 6: M4), the fifth metatarsal bone (Zone 7: M5), the midfoot (Zone 8: MF), the medial heel (Zone 9: HM) and the lateral heel (Zone 10: $\mathrm{HL}$ ). All the above zones were discussed in our analysis.

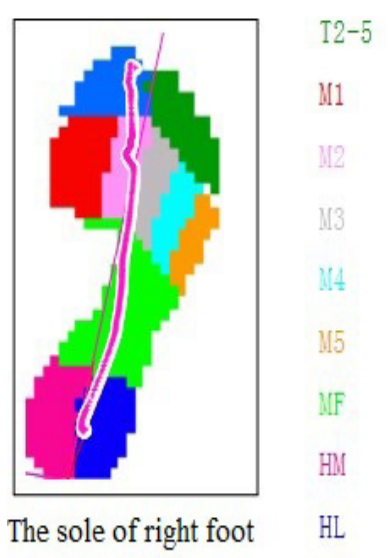

Figure 2. Pressure zones of the foot

\section{EXPERIMENTAL RESULTS AND ANALYSIS}

\section{Analysis on Gait Features}

The gait features of the test group and the control group are recorded in Table 2 .

The data in Table 2 show obvious differences between the test group and the control group in the following gait features: percentage of support phase, step length, motion speed and the sagittal plane motion range of ankle. Compared with ordinary people, the volleyball players had large step length, fast 
motion speed, and large ankle motion range on the sagittal plane. In addition, the differences were still prominent after data normalization, indicating that they are related to the sports of volley rather than weight and height. Many scholars held that motion speed is positively correlated with the sagittal plane motion range of ankle. However, our experimental results show that the volleyball players had a smaller sagittal plane motion range of ankle, despite their faster motion speed, that is, a faster motion speed does not necessarily lead to a larger ankle motion range on the sagittal plane. This finding can be attributed to the significant different gaits between the players and ordinary people.

Table 2: Comparison between test group and control group in gait features

\begin{tabular}{ccccc}
\hline Parameters & $\begin{array}{c}\text { Test Group } \\
(\mathrm{N}=30)\end{array}$ & $\begin{array}{c}\text { Injured subgroup } \\
(\mathrm{N}=19)\end{array}$ & $\begin{array}{c}\text { Uninjured } \\
\text { subgroup }(\mathrm{N}=11)\end{array}$ & $\begin{array}{c}\text { Control Group } \\
(\mathrm{N}=17)\end{array}$ \\
\hline Gait cycle $(\mathrm{s})$ & $1.04 \pm 0.08$ & $1.02 \pm 0.09$ & $1.07 \pm 0.09$ & $1.01 \pm 0.08$ \\
Percentage of support phase $(\%)$ & $59.32 \pm 1.19^{*}$ & $58.13 \pm 0.92^{*}$ & $59.96 \pm 1.11$ & $63.02 \pm 2.06$ \\
Step length $(\mathrm{m})$ & $1.55 \pm 0.08^{*}$ & $1.58 \pm 0.09$ & $1.52 \pm 0.16$ & $1.24 \pm 0.17$ \\
Motion speed $(\mathrm{m} / \mathrm{s})$ & $1.46 \pm 0.07^{*}$ & $1.47 \pm 0.08$ & $1.44 \pm 0.05$ & $1.26 \pm 0.15$ \\
Maximum knee flexion angle $\left({ }^{\circ}\right)$ & $62.18 \pm 4.29$ & $61.39 \pm 3.97$ & $63.76 \pm 4.75$ & $60.23 \pm 6.52$ \\
Sagittal plane motion range of ankle $\left(^{\circ}\right)$ & $20.67 \pm 2.77^{*}$ & $20.63 \pm 2.32^{*}$ & $21.22 \pm 3.79$ & $23.34 \pm 4.09$ \\
Sagittal plane motion range of knee $\left(^{\circ}\right)$ & $58.75 \pm 3.74$ & $57.99 \pm 4.03$ & $60.32 \pm 3.24$ & $58.87 \pm 5.98$ \\
Sagittal plane motion range of hip $\left(^{\circ}\right)$ & $36.51 \pm 2.34$ & $36.03 \pm 2.26$ & $37.33 \pm 2.31$ & $36.79 \pm 6.47$ \\
\hline
\end{tabular}

Note: The figures in the table are the mean values of the relevant parameters of each group; the mean values of relevant parameters of each group were compared by nonparametric estimation, and the parameters with significant difference between the two groups were marked with asterisk(s); ${ }^{*} \mathrm{P}<0.05$ (Comparison between the test group and the control group).

It can be seen from Table 2 that the injured subgroup had a much smaller percentage of support phase than the uninjured group, revealing that the percentage should be reduced to control the further pressure damage on the injured parts. Moreover, the uninjured group exhibited a much larger motion range of ankle on the sagittal plane. This is consistent with the results of the comparison between the test group and the control group. The injured and uninjured groups had no major differences in step length and motion speed, which excludes step length and motion speed from the main causes of sports injuries.

\section{Analysis on Plantar Pressure}

The plantar pressures of the test group and the control group detailed in Table 3 below.

Table 3: The plantar pressures of the test group and the control group

\begin{tabular}{ccc}
\hline Pressure zones of the foot (PSI) & Test group (N=30) & Control group (N=17) \\
\hline Zone 1: T1 & $3.30 \pm 1.05$ & $3.46 \pm 1.54$ \\
Zone 2: T2 5 & $0.86 \pm 0.53$ & $0.79 \pm 0.33$ \\
Zone 3: M1 & $2.63 \pm 0.81$ & $2.85 \pm 0.72$ \\
Zone 4: M2 & $3.37 \pm 1.63^{*}$ & $4.82 \pm 1.22$ \\
Zone 5: M3 & $3.36 \pm 1.21$ & $3.90 \pm 1.36$ \\
Zone 6: M4 & $3.36 \pm 1.91^{*}$ & $1.78 \pm 0.35$ \\
Zone 7: M5 & $3.03 \pm 1.89^{*}$ & $1.23 \pm 0.59$ \\
Zone 8: MF & $3.07 \pm 1.24$ & $3.16 \pm 0.53$ \\
Zone 9: HM & $4.62 \pm 1.34^{*}$ & $6.37 \pm 1.14$ \\
Zone 10: HL & $4.82 \pm 1.12$ & $4.94 \pm 1.12$ \\
\hline
\end{tabular}

Note: ${ }^{*} \mathrm{P}<0.05$ (Comparison between the test group and the control group); To exclude the impact of weight on plantar pressure, all plantar pressures were the pressure per unit of plantar area calculated by the PSI method. 
Comparing the results of the test and control groups, it can be seen that the plantar pressure of volleyball players was distributed evenly across metatarsal bones, but highly uniformly on the second, fourth and fifth toes and the medial heel. This phenomenon deviates far from the agreement among many scholars that the plantar pressure is distributed relatively evenly [15-18]. The deviation reflects the difference between volleyball players and ordinary people in plantar pressure distribution, owing to the special motions (dominated by running and jumping) in the sport of volleyball.

The plantar pressures of the injured and uninjured subgroups are given in Table 4 below.

Table 4: The plantar pressures of the injured and uninjured subgroups

\begin{tabular}{ccc}
\hline Pressure zones of the foot (PSI) & Injured subgroup & Uninjured subgroup \\
\hline Zone 1: T1 & $3.06 \pm 1.10$ & $3.73 \pm 1.08$ \\
Zone 2: T2 5 & $0.99 \pm 0.58^{*}$ & $0.63 \pm 0.31$ \\
Zone 3: M1 & $1.91 \pm 0.95^{*}$ & $3.88 \pm 1.21$ \\
Zone 4: M2 & $2.38 \pm 0.97^{*}$ & $5.07 \pm 1.01$ \\
Zone 5: M3 & $3.77 \pm 1.06^{*}$ & $2.64 \pm 1.17$ \\
Zone 6: M4 & $4.94 \pm 1.21^{*}$ & $1.62 \pm 0.45$ \\
Zone 7: M5 & $4.19 \pm 1.37^{*}$ & $1.03 \pm 0.35$ \\
Zone 8: MF & $3.41 \pm 1.27^{*}$ & $2.47 \pm 0.94$ \\
Zone 9: HM & $4.35 \pm 1.28$ & $5.08 \pm 1.36$ \\
Zone 10: HL & $4.91 \pm 1.00$ & $4.67 \pm 1.34$ \\
\hline
\end{tabular}

Note: Compared with the control group ${ }^{*} \mathrm{P}<0.05$; To exclude the impact of weight on plantar pressure, all plantar pressures were the pressure per unit of plantar area calculated by the PSI method.

The injured subgroup suffered from much greater pressure in the second to fifth toes, the fifth metatarsal bone and the midfoot than the uninjured subgroup, and much smaller pressure in the first and second metatarsal bones. The plantar pressure distributions of the two subgroups were plotted into pressure maps (Figure 3), where the orange and red areas indicate high pressure and the green area indicate low pressure. It is generally believed that, the greater and more unevenly distributed the plantar pressure, the higher the risk of sports injuries. In particular, an extremely high pressure often results in arch collapse. These ideas were confirmed by our research results.

Besides the difference in plantar pressure distribution, the injured and uninjured subgroups

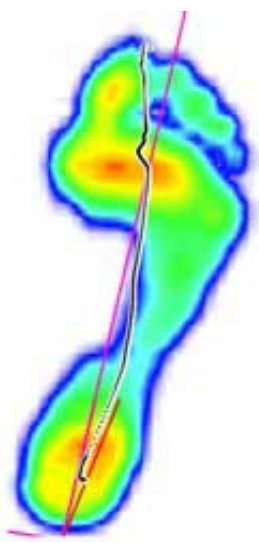

(a) Uninjured subgroup differed greatly in the gravity pressure line. As shown in Figure 3, the gravity pressure line of the injured subgroup was closer to the peripherals of the sole than that of the uninjured group. This demonstrates a defect in the gait of the subjects in the injured subgroup: in most cases, the external contour of the foot is the main place to withstand pressure. The outward shift in gravity pressure line can also be considered as a sign of protective compensation: the plantar pressure distribution of the injured subgroup reflects the adaptation to the injury; with the shift in gravity pressure line, the lateral of foot starts to carry more pressure, thus reducing the load on the injured places.

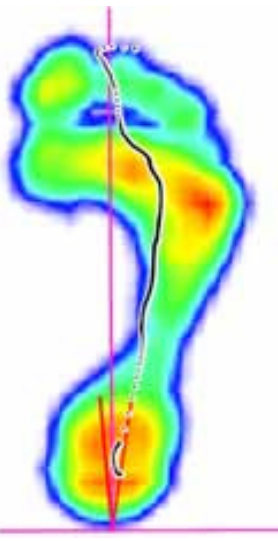

(b) Injured subgroup

Figure 3 . The gravity pressure lines of the injured and uninjured subgroups 
The above differences in plantar pressure were well demonstrated in the plantar pressure curves of Figures 4 and 5. These curves were plotted based on the mean plantar pressure of all members in each group. To exclude the impact of weight on plantar pressure, all plantar pressures were the pressure per unit of plantar area calculated by the PSI method. Specifically, the pressures on the first and second metatarsal bones of the injured subgroup were much smaller than those of the injured subgroup, as evidenced by the decline in curve peaks. In all other zones, the injured subgroup exceeded the uninjured subgroup to different extends in pressure (curve peaks). The pressure growth was particularly obvious on the fourth and fifth metatarsal bones.

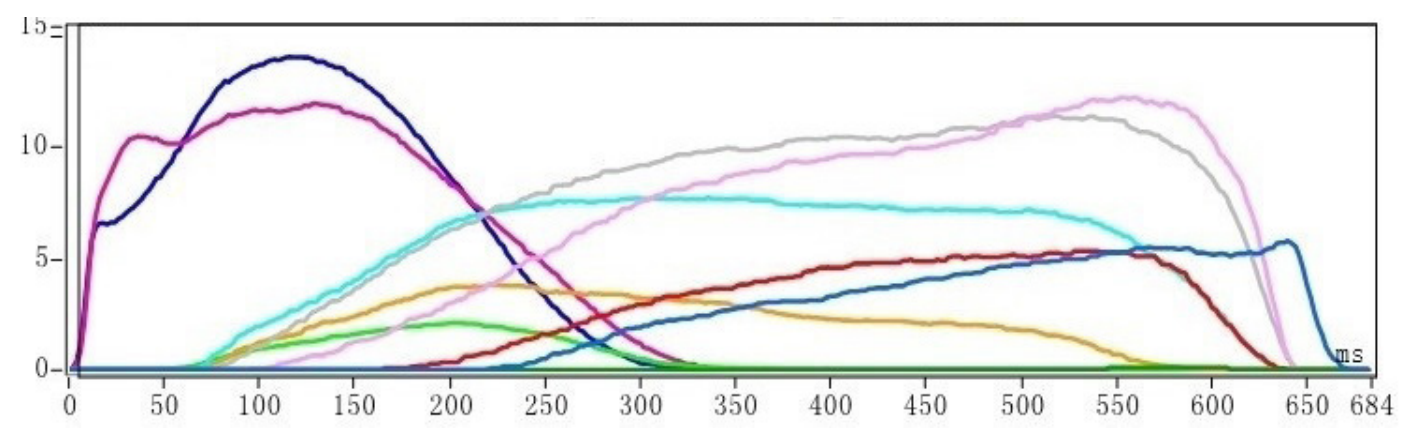

Figure 4. The plantar pressure curve of uninjured subgroup

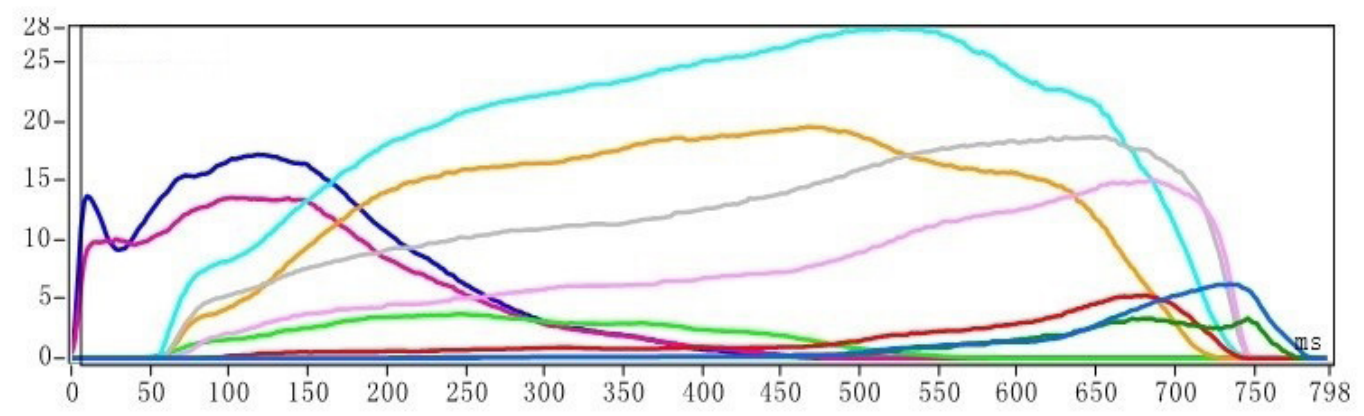

Figure 5. The plantar pressure curve of injured subgroup

\section{SUMMARY}

Through the comparative analysis above, it is clear that the plantar pressure distribution of volleyball players has a close correlation with their gait features. Due to the unique gait features, the plantar pressure of volleyball players differs greatly from that of ordinary people, increasing the risk of sports injuries. The volleyball players have significant differences in both gait features and plantar pressure distribution from ordinary people. Moreover, injured volleyball players differ greatly in plantar pressure distribution with uninjured ones.

\section{CONCLUSIONS}

Volleyball players are much more likely to get injured than ordinary people, due to their unique distribution of plantar pressure. However, the existing studies have not fully analyzed the causes of the difference between volleyball players and ordinary people in plantar pressure. Neither have they understood if excess plantar pressure could cause foot injury of volleyball players. The lack of relevant research makes it difficult to provide proper measures to prevent foot injury of volleyball players. For the first time, this research introduces gait features into the analysis on plantar pressure of volleyball players, and discloses the root causes of the difference between them and ordinary people in plantar pressure. The author pointed out that, to reduce the risk of sports injuries, the volleyball players should ease their plantar pressure by adjusting gait. The main conclusions are as follows:

(1) Compared with ordinary people, volleyball players have large step length and 
fast motion speed, but small range of ankle on the sagittal plane. These are the unique gait features of volleyball players, which leads to the uncommon plantar pressure distribution.

(2) The injured volleyball players have more uneven distribution of plantar pressure than the uninjured. In addition, the plantar pressure of the injured players is borne in areas closer to the peripheral of the foot than that of the uninjured, as evidenced by the outward shift of the gravity pressure line. These results may be attributed to the protective compensation, an adaptive response of the injured players.

(3) The gait features directly bear on the plantar pressure distribution of volleyball players. To effectively reduce the injury risk, the plantar pressure should be distributed more evenly by adjusting the gait features (e.g. avoiding toe-in gait, toe-out gait and foot eversion).

(4) The main contribution of this paper is as follows: For the first time, it is proved that volleyball players have different gait features from ordinary people, and that the special gait features affect the plantar pressure distribution of these players. It is also demonstrated that injured volleyball players differ with non-injured ones in gait features and plantar pressure. The results indicate that gait features are an important cause of injury among athletes. On this basis, the author concluded that it is possible to reduce the occurrence of foot injury among volleyball players by adjusting their gait features.

(5) On limitations, this paper mainly focuses on how volleyball players are affected by gait features and the resulting changes in plantar pressure. In fact, the gait features are not the only influencing factor of the plantar pressure distribution of volleyball players. For example, the various rhythms of steps and techniques of jumping/landing required for volleyball playing may also increase the plantar pressure and cause injuries. The future research will explore other influencing factors of excessive plantar pressure of volleyball players, put forward targeted countermeasures, and verify if gait features could affect the plantar pressure and injury occurrence of players in other sports.

\section{Acknowledgements}

Used rubber was the main material used to prepare training tennis 18ZB0547.

\section{REFERENCES}

1. Imaizumi, K., Iwakami, Y., Yamashita, K., Effect of foot load changes on foot arch evaluation using foot pressure distribution data, J Foot Ankle Res, 2014, 7, S1, A114, https://doi. org/10.1186/1757-1146-7-s1-a114.

2. Zahradnik, D., Uchytil, J., Farana, R., Jandacka, D., Ground reaction force and valgus knee loading during landing after a block in female volleyball players, J Hum Kinet, 2014, 40, 1, 67, https://doi.org/10.2478/hukin-2014-0008.

3. Bolach, B., Stańdo, M., Bolach, E., Training load in direct start preparation (dsp) in sitting volleyball players, Physiotherapy, 2017, 23, 4, https://doi.org/10.1515/physio-2015-0022.

4. Lobietti, R., Fantozzi, S., Stagni, R., Merni, F., Kinematics analysis of landing from volleyball block, Gait Posture, 2008, 28, S19, https:// doi.org/10.1016/j.gaitpost.2007.12.037.

5. Cappozzo, A., Critical issues in the reconstruction of bone position and orientation during movement, Gait Posture, 1995, 3, 3, 171-171, https://doi. org/10.1016/0966-6362(95)99072-s.

6. Riva, F., Bisi, M.C., Stagni, R., Orbital stability analysis of voluntarily altered gait pattern, Gait Posture, 2012, 35, S1, S3-S4, https://doi. org/10.1016/j.gaitpost.2011.09.025.

7. Schmid, O.A., Schöllhorn, W.I., Bauer, H.U., Gait pattern analysis using selforganizing neural networks, Gait Posture, 1997, 6, 3, 268-269, https://doi.org/10.1016/s09666362(97)90066-7.

8. Hughes, J., Clark, P., Jagoe, R.R., Gerber, C., Klenerman, L., The pattern of pressure distribution under the weight bearing forefoot, Foot, 1991, 1, 3, 117-124, https:// doi.org/10.1016/0958-2592(92)90045-q.

9. Atkinson-Smith, C., Betts, R.P., The relationships between footprints, foot pressure distributions, rearfoot motion and foot function in runners, Foot, 1992, 2, 3, 148-154, https://doi.org/10.1016/09582592(92)90063-u. 
10. Dedieu, P., Zanone, P.G., Effects of gait pattern and arm swing on intergirdle coordination, Hum Mov Sci, 2012, 31, 3, 660-671, https:// doi.org/10.1016/j.humov.2011.07.009.

11.Begon, M., Monnet, T., Lacouture, P., Effects of movement for estimating the hip joint centre, Gait Posture, 2007, 25, 3, 353-359, https:// doi.org/10.1016/j.gaitpost.2006.04.010.

12.Cromwell, R.L., Movement strategies for head stabilization during incline walking, Gait Posture, 2003, 17, 3, 246-53, https://doi. org/10.1016/s0966-6362(02)00094-2.

13.Jc, V.D.N., Schaffers, I., Snijders, J., Harlaar, J., The effectiveness of voluntary modifications of gait pattern to reduce the knee adduction moment, Hum Mov Sci, 2013, 32, 3, 412-24, https://doi.org/10.1016/j. humov.2012.02.009.

14.Ancillao, A., van der Krogt, M., Buizer, A.I., Witbreuk, M.M., Cappa, P., Harlaar, J., Analysis of gait patterns pre- and post- single event multilevel surgery in children with cerebral palsy by means of offset-wise movement analysis profile and linear fit method, Hum Mov Sci, 2017, 55, 145-155. https://doi. org/10.1016/j.humov.2017.08.005.
15.Morris, J., Kinematic measurement of human movement, Gait Posture, 1995, 3, 3, 170-170, https://doi.org/10.1016/09666362(95)99068-v.

16.Banz, R., Bolliger, M., Colombo, G., Lünenburger, L., Movement analysis with the driven gait orthosis lokomat, Gait Posture, 2006, 24, S215-S216. https://doi. org/10.1016/j.gaitpost.2006.11.148.

17. Witte, K., Schobesberger, H., Peham, C., Motion pattern analysis of gait in horseback riding by means of principal component analysis, Hum Mov Sci, 2009, 28, 3, 394-405, https://doi. org/10.1016/j.humov.2009.04.002.

18. Uhlrich, S.D., Silder, A., Beaupre, G.S., Shull, P.B., Delp, S.L., Subject-specific toe-in or toe-out gait modifications reduce the larger knee adduction moment peak more than a non-personalized approach, J Biomech, 2018, 66, 103-110. https://doi.org/10.1016/j. jbiomech.2017.11.003.

(C) 2019 by the author(s). Published by INCDTPICPI, Bucharest, RO. This is an open access article distributed under the terms and conditions of the Creative Commons Attribution license (http:// creativecommons.org/licenses/by/4.0/). 